ŹRÓDŁA, MATERIAŁY, MISCELLANEA

http://dx.doi.org/10.15762/ZH.2019.20

KAROL KŁODZIŃSKI

(Uniwersytet Gdański)

\author{
Margarete Bieber (1879-1978) - \\ WYBITNA BADACZKA KULTURY ANTYCZNEJ Z PRUS ZACHODNiCH
}

Słowa kluczowe: Przechowo, emancypacja kobiet, kultura starożytna, archeologia klasyczna, kobiety nauki

W kontekście pytań o udział kobiet w tworzeniu nauki w XX w. palma pierwszeństwa, jak powszechnie wiadomo, należy się Marii Skłodowskiej-Curie, która nie tylko była pierwszą, dwukrotną laureatką Nagrody Nobla (w 1903 i 1911 r.), lecz także pierwszą kobietą-profesorem na paryskiej Sorbonie $^{1}$. Wnikliwsze studia przekonują jednak, że w minionym wieku słynna polska chemiczka nie była jedyną tak zasłużoną dla nauki uczoną. Imponujące są także osiągnięcia oraz dorobek naukowy niemieckiej (od 1940 r. mającej obywatelstwo amerykańskie) badaczki pochodzenia żydowskiego - Margarete Bieber. Ta urodzona 31 VII 1879 r. w Przechowie (Schönau, obecnie dzielnica Świecia $)^{2}$ na obszarze dawnych Prus Zachodnich uczona była światowej sławy znawczynią sztuki i archeologii starożytnej Grecji i Rzymu, wyspecjalizowaną w historii teatru antycznego. Kariera tej badaczki to przede wszystkim fascynująca historia zmagań zainteresowanej kulturą starożytną córki bogatych pomorskich przemysłowców o żydowskich korzeniach, która pragnąc poświęcić się nauce, przez długi czas musiała walczyć z uprzedzeniami dotyczącymi nie tylko jej płci, lecz także przynależności etnicznej, szczególnie napiętnowanej w okresie hitlerowskich Niemiec.

Pod koniec XIX i na początku XXw. zdobycie wyższego wykształcenia, a tym bardziej zaistnienie w światowej nauce, dla zdecydowanej większości kobiet było nieosiągalne $e^{3}$ Swój naukowy sukces M. Bieber zawdzięczała jed-

${ }^{1}$ Shari Rudavsky, Marie Curie 1867-1934, [in:] Notable Scientists from 1900 to the Present, vol. 1: A-C, ed. Brigham Narins, Farmington Hills 2001, s. 498-499.

${ }^{2}$ Archiwum Państwowe w Bydgoszczy, USC w Przechowie, sygn. 6/1763/0/2.1/32, nr 34 (1879).

${ }^{3}$ Harriet Pass Freidenreich, Female, Jewish, Educated. The Lives of Central European University Women, Bloomington 2002, s. 4-10. Według wyliczeń Harriet Pass Freidenreich przed 
nak nie swojej pozycji społecznej (choć jej rodzina była bardzo majętna i dość długo finansowała badania uczonej), lecz nieprzeciętnej sile charakteru, wyjątkowemu talentowi oraz niezwykłej pracowitości, które pozwoliły jej oraz innym kobietom pochodzenia żydowskiego na zrobienie kariery akademickiej na początku wieku $\mathrm{XX}^{4}$. Nie bez znaczenia było także początkowe, solidne wykształcenie, które przyszła uczona zdobyła w Przechowie, Dreźnie i Berlinie ${ }^{5}$. Co interesujące, była ona pierwszą kobietą pochodzącą z Prus Zachodnich, która we wrześniu 1901 r. w gimnazjum toruńskim złożyła egzamin maturalny, otrzymując ze wszystkich przedmiotów (oprócz matematyki) ocenę „bardzo dobry”. Jako pierwsza kobieta odniosła ogromny sukces, otrzymując stypendium na wyjazd zagraniczny, przyznawane przez Niemiecki Instytut Archeologiczny (Kaiserlich-Deutsches Archäologisches Institut - DAI) (1909/1910). Również jako pierwsza kobieta w 1913 r. została członkiem-korespondentem $\mathrm{DAI}^{7}$ oraz wreszcie tuż po zakończeniu I wojny światowej w 1919 r. jako pierwsza kobieta na Uniwersytecie w Gießen uzyskała habilita$\mathrm{cję}^{8}$. Ponadto jako druga kobieta na uniwersytetach niemieckich objęła stanowisko wykładowcy (Privatdozentin) na Uniwersytecie w Gießen, jako pierwsza w zakresie archeologii klasycznej'. Już po II wojnie światowej, w latach 1949-1951, jako pierwsza kobieta (nie licząc lektorek języków obcych) wykładała jako visiting professor na Uniwersytecie Princeton ${ }^{10}$. Powyższe informacje

epoką hitlerowskich Niemiec jedynie 84 kobiety zrobily karierę akademicką (przez uzyskanie habilitacji) na uniwersytetach niemieckich i austriackich, co nie przekraczało $1,2 \%$ wszystkich działających tam uczonych. W gronie tych kobiet 32 były pochodzenia żydowskiego: $11 \mathrm{w}$ naukach humanistycznych, $7 \mathrm{w}$ matematycznych, 5 w społecznych oraz 9 - medycznych; ibid., s. 73 .

${ }^{4}$ Ibid., s. $74-75$.

${ }^{5} \mathrm{Na}$ temat swego rodzaju „klimatu kulturowego” i solidności pruskiej szkoły ostatnio zob. Tomasz Krzemińsкi, Małe miasta Pomorza Nadwiślańskiego w dobie przemian cywilizacyjnych XIX wieku. Społeczność lokalna między zacofaniem a modernizacja, [in:] Naród bez państwa na drogach do nowoczesności. Książka jubileuszowa w 70. rocznicę urodzin Szczepana Wierzchosławskiego, red. Magdalena NiedzIELSKA, Toruń 2017, s. 116-120.

${ }^{6}$ Hans-Günter Buchнolz, Margarete Bieber (1879-1978) / Klassische Archäologin, [in:] Gießener Gelehrte in der ersten Hälfte des 20. Jahrhunderts, Bd. 1, hrsg. v. Hans Georg GundeL, Peter Moraw, Marburg 1982, s. 58; Hans Peter Obermayer, Deutsche Altertumswissenschaftler im amerikanischen Exil. Eine Rekonstruktion, Berlin-Boston 2014, s. 37. Szerzej zob. przyp. 42.

${ }^{7}$ W 1922 r. Bieber została członkiem zwyczajnym DAI. Zob. Matthias Recke, Bieber, Margarete, [in:] Geschichte der Altertumswissenschaften. Biographisches Lexikon, hrsg. v. Peter KuHLmann, Helmuth Schneider (Der Neue Pauly. Supplemente, Bd. 6), Stuttgart-Weimar 2012, col. 103.

${ }^{8}$ H. P. Obermayer, op.cit., s. 37; M. Recke, op.cit., col. 104.

${ }^{9}$ H.-G. Buchiolz, op.cit., s. 62.

${ }^{10}$ Larissa Bonfante, Margarete Bieber (1879-1978): An Archaeologist in Two Worlds, [in:] Women as Interpreters of the Visual Arts, ed. Claire Richter Sherman, Adele M. Holcomb, Westport 1981, s. 257. 
przekonują, że postać oraz dorobek naukowy tej uczonej, szczególnie docenianej w nauce niemieckiej i amerykańskiej ${ }^{11}$, powinny zainteresować także polskich badaczy ${ }^{12}$.

Margarete Bieber urodziła się w Przechowie ${ }^{13}$ w zasymilowanej rodzinie niemieckiej pochodzenia żydowskiego jako druga z czwórki dzieci Jaco-

${ }^{11} \mathrm{~W}$ literaturze światowej badaczce tej poświęcono już kilka biogramów oraz szczegółowych studiów. Wciąż jednak nie doczekała się ona osobnej biografii. Zob. np. Larissa BonfanTE, Margarete Bieber (1879-1978), Gnomon, vol. 51: 1979, s. 621-624; idem, Margarete Bieber (1879-1978): An Archeologist in Two Worlds, s. 239-274 (najpełniejsza analiza jej biografii i dorobku sporządzona m.in. na podstawie niepublikowanej autobiografii uczonej - „Memoirs of a female Scholar" z 1959 r.); H.-G. BuchHolz, op.cit., s. 58-73; Hugo Rasmus, Lebensbilder Westpreussischer Frauen in Vergangenheit und Gegenwart, Münster/Westf. 1984, s. 27; Walter Tetzlaff, Bieber, Margarete, [in:] Altpreussische Biographie, Bd. 4/2, hrsg. v. Ernst Bahr, Gerd Brausch, Marburg/Lahn 1989, s. 1181; Hugo Rasmus, Schwetz (Świecie n. W.) an der Weichsel. Stadt und Kreis. Natur - Geschichte - Wirtschaft - Kultur, Münster/Westf. 2001, s. 246-247; Ann Thomas Wilkins, Bieber, Margarete, [in:] Notable American Women. A Biographical Dictionary Completing the Twentieth Century, ed. Susan Ware, Stacy Braukman, Harvard 2004, s. 56-57; Matthias RECKE, „... besonders schauerlich war die Anwesenheit von Frl. Bieber”. Die Archäologin Margarete Bieber (1879-1978) - Etablierung einer Frau als Wissenschaftlerin, [in:] Science oder Fiction? Geschlechterrollen in archäologischen Lebensbildern, hrsg. v. Jana Esther FrIEs, Ulrike Rambuscheck, Gisela Schulte-Dornberg, Münster 2007, s. 209-231; idem, Margarete Bieber (1879-1978) - Vom Kaiserreich bis in die Neue Welt. Ein Jahrhundert gelebte Archäologie gegen alle Widerstände, [in:] Ausgräberinnen, Forscherinnen, Pionierinnen. Ausgewählte Porträts früher Archäologinnen in Kontext ihrer Zeit, hrsg. v. Jana Esther FrIES, Doris GuTSMIEdL-SchüMAnN, Münster 2013, s. 141-149; idem, Bieber, Margarete, col. 103-105. Zestawienie prac M. Bieber zob. Larissa BONFANTE, Rolf Winkes, Bibliography of the Works of M. Bieber for her $90^{\text {th }}$ Birthday, New York 1969; Lexikon deutsch-jüdischer Autoren, Bd. 2, hrsg. v. Renate Heuer, München-New Providence-London-Paris 1993, s. 419-423.

${ }^{12} \mathrm{~W}$ polskiej historiografii można znaleźć dwie, dość skrótowe wzmianki na temat M. Bieber, skupiające się głównie na „wyjątkowym” fakcie uzyskania matury przez pierwszą kobietę z Prus Zachodnich. Zob. Magdalena Niedzielska, Życie polityczne i kulturalne Torunia (1815-1914), [in:] Historia Torunia, t. 3, cz. 1: W czasach zaboru pruskiego (1793-1920), red. Marian Biskup, Toruń 2003, s. 318; Krystyna Podlaszewska, Gimnazjum Toruńskie w latach 1817-1920, Toruń 2007, s. 180, przyp. 55. Jedynym przygotowanym w języku polskim biogramem M. Bieber jest okolicznościowy szkic biograficzny o charakterze popularnonaukowym autorstwa Lidii Smentek. Zob. Lidia Smentek, Nawojka Gimnazjum Toruńskiego: Margarete Bieber, Zeszyty Literackie i Naukowe I LO im. Mikołaja Kopernika w Toruniu, nr 4: 2018, s. 21-58. Niestety tekst ten, choć zawiera ilustracje i interesujące informacje na temat uczonej z Przechowa, nie został opatrzony aparatem naukowym. Zob. także Piotr Skuczyński, Przechowo. Album z zarysem dziejów, Świecie 2014, s. 84 (krótka notka o M. Bieber opracowana na podstawie witryny internetowej).

${ }^{13} \mathrm{~W}$ drugiej połowie lat sześćdziesiątych XIX w. wieś Przechowo pod względem liczby mieszkańców była jedną z największych w powiecie świeckim ( 829 mieszkańców: 411 katolików, 396 ewangelików, 22 Żydów). Zob. Emil JACOBson, Topographisch-statistisches Handbuch für die Regierungsbezirk Marienwerder, Danzig 1868, s. 166-167. Ta sytuacja nie zmieniła się na początku XX w. Ze spisu powszechnego przeprowadzonego w rejencji kwidzyńskiej 1 XII $1910 \mathrm{r}$. wynika, że w Przechowie mieszkało 1430 osób, w tym tych, którzy wybrali jako język ojczysty: 
ba Biebera ${ }^{14}$ oraz Valli Bukofzer ${ }^{15}$. Ojciec Margarete, „żyd milioner”16, który być może sam interesował się sztuką antyczną ${ }^{17}$, był wpływowym i zamożnym przedsiębiorcą z tytułem Kommerzienrat ${ }^{18}$. W Adress-Buch der Stadt Graudenz und Feste Courbiere z 1901 r. został wspomniany jako fabrykant z Przechowa, członek Izby Handlowej w Grudziądzu ${ }^{19}$. Z kolei w Güter-Adreßbuch für die

niemiecki 750 (596 ewangelików, 99 katolików, 39 członków innych Kościołów oraz 16 Żydów), polski 658 (wszyscy wyznania katolickiego), inny język obcy (1) oraz język niemiecki i inny język obcy (22). Zob. Gemeindelexikon für die Regierungsbezirke Allenstein, Danzig, Marienwerder, Posen, Bromberg und Oppeln. Auf Grund der Ergebnisse der Volkszählung vom 1. Dezember 1910 und anderer amtlicher Quellen, H. 3: Regierungsbezirk Marienwerder, Berlin 1912, s. 62-63.

${ }^{14}$ W styczniu 1901 r. niejaki Bieber, prawdopodobnie ojciec Margarete, określony w „Thorner Presse” jako „Guts- und Mühlenbesitzer zu Schönau, Kreis Schwetz”, został odznaczony Królewskim Orderem Korony III klasy. Zob. Thorner Presse, 1901, nr 18, s. 5.

${ }^{15} \mathrm{Z}$ pewnością żydowska rodzina Bukofzer $\mathrm{z}$ Przechowa również należała do majętnych. W przeciwieństwie jednak do J. Biebera i jego żony, którzy w 1921 r. optowali na rzecz Niemiec i wyjechali do Berlina, Bukofzerowie pozostali w polskim Przechowie. Artur Bukofzer, kupiec zajmujący się handlem zbożem i ok. 1926 r. zamieszkały w Świeciu przy ul. Klasztornej 1 (Ksiega adresowa przemysłu, handlu i rzemiosła Zachodniej Polski (Wielkopolski, Pomorza, Śląska i w. m. Gdańska), Poznań 1926, P 100), sekretarz Gminy Wyznaniowej Żydowskiej Świecie-Nowe-Gniew w 1933 r., był „właścicielem pięciu budynków o wartości 70 tys. zł, 3 ha ziemi oraz składu ziemiopłodów i towarów kolonialnych"; zob. Mirosław Golon, Gmina Wyznaniowa Żydowska w Świeciu nad Wisłą w latach 1920-1939, [in:] Stosunki narodowościowe i wyznaniowe na Pomorzu w XIX i XX w., t. 4: Gminy Wyznaniowe Żydowskie w województwie pomorskim w okresie międzywojennym (1920-1939), red. Jan SzILING, Toruń 1995, s. 186. Do wspomnianych pięciu budynków należały m.in. kamienice oraz spichlerz; zob. Zbigniew KARPus, Żydzi w Świeciu i powiecie w okresie międzywojennym, [in:] Emancypacja - asymilacja - antysemityzm. Żydzi na Pomorzu w XIX i XX wieku, red. Zenon Hubert NowaK, Toruń 1992, s. 113.

${ }^{16}$ Gazeta Toruńska, 1913, nr 217, s. 1.

${ }^{17}$ Niewykluczone, że ojciec Margarete posiadał (być może kolekcjonował?) zabytki antyczne. Zob. Chronik der Friedrich-Wilhelms-Universität zu Berlin für das Rechnungsjahr 1914, Jg. 28, Halle 1915, s. 85: „An erster Stelle haben wir Herrn Kommerzienrat Bieber in Schönau für eine römische Bronzestatuette, Apollo im Typus der berühmten Kasseler Statue, zu danken”.

${ }^{18}$ W 1910 r. Kommerzienrat Jacob Bieber z Przechowa został wymieniony na liście członków wspierających, a w latach 1911-1914 na liście darczyńców berlińskiego Instytutu Nauk Judaistycznych (Lehranstalt für die Wissenschaft des Judentums). Zob. Achtundzwanzigster Bericht der Hochschule für die Wissenschaft des Judenthums in Berlin, Berlin 1910, s. 30; Neunundzwanzigster Bericht der Hochschule für die Wissenschaft des Judenthums in Berlin, Berlin 1911, s. 39; Dreissigster Bericht der Hochschule für die Wissenschaft des Judenthums in Berlin, Berlin 1912, s. 40; Einunddreissigster Bericht der Hochschule für die Wissenschaft des Judenthums in Berlin, Berlin 1913, s. 35; Zweiunddreissigster Bericht der Hochschule für die Wissenschaft des Judenthums in Berlin, Berlin 1914, s. 40. Szerzej na temat działalności Instytutu Nauk Judaistycznych w Berlinie zob. Rafał ŻEBrowski, Hochschule für die Wissenschaft des Judentums, [in:] Polski Słownik Judaistyczny. Dzieje, kultura, religia, ludzie, t. 1, opr. Zofia Borzymińsкa, Rafał Żebrowski, Warszawa 2003, s. 605.

${ }^{19}$ Adress-Buch der Stadt Graudenz und Feste Courbiere. Ausgabe 1901, Graudenz 1902, s. XV. 
[433] Margarete Bieber (1879-1978) - wybitna badaczka kultury antycznej...

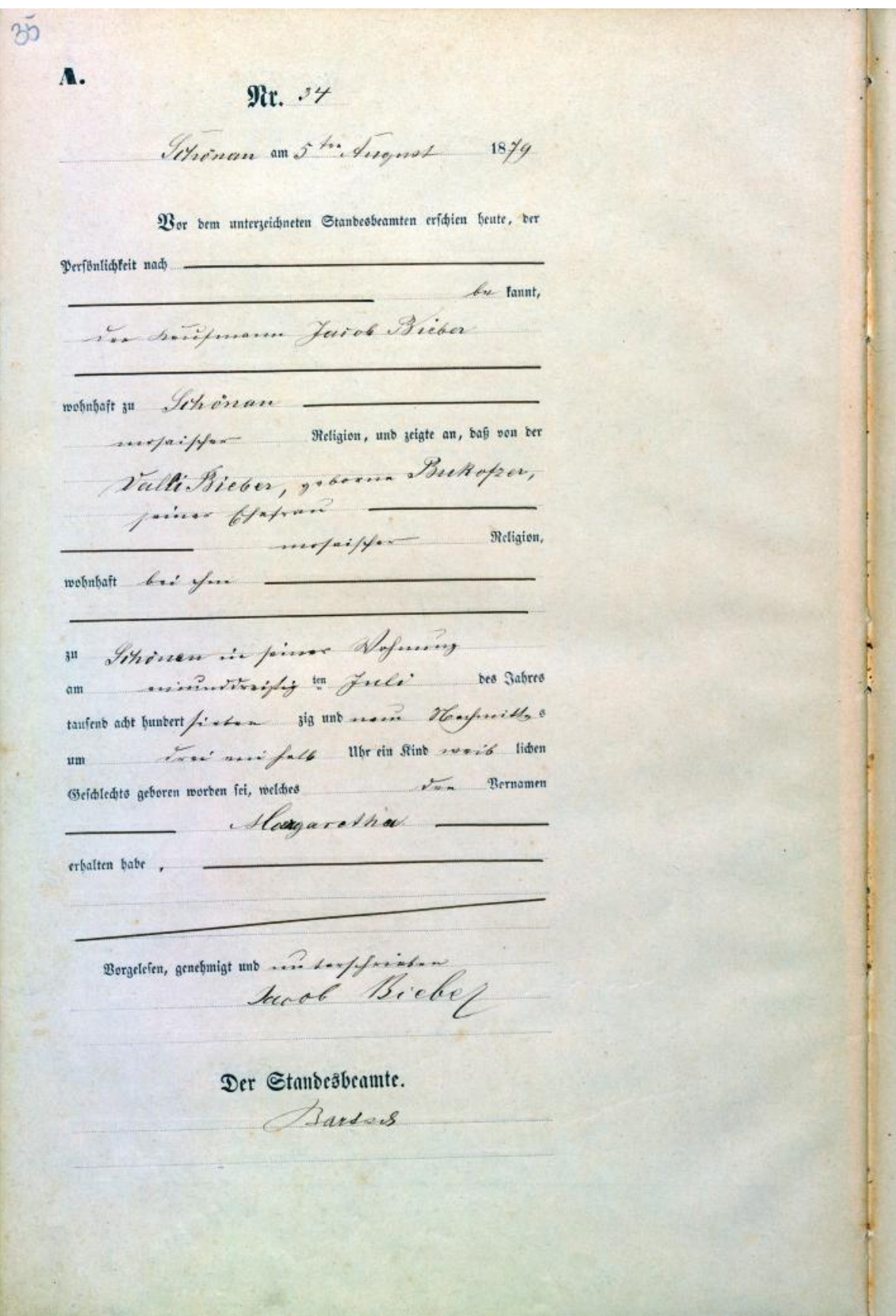

1. Akt urodzenia Margarete Bieber (Archiwum Państwowe w Bydgoszczy, USC w Przechowie, sygn. 6/1763/0/2.1/32, nr 34 (1879)) 
Provinz Westpreussen z 1912 r. został zapisany jako ewangelik, jeden z dwóch (obok Friedricha Kuchenbeckera) właścicieli dóbr ziemskich (82 ha) w Przechowie $^{20}$. Już w $1894 \mathrm{r}$. Bieber miał dwa młyny zbożowe (w tym parowy) i tartak $^{21}$. W 1900 r. tartak firmy H. Bieber, w którym pracowało 40 robotników, drugi pod względem wielkości w powiecie świeckim, przecierał 11500 m.b. drewna $^{22}$. O znacznym majątku i możliwościach finansowych właścicieli młynów świadczy chociażby zorganizowanie we wrześniu $1897 \mathrm{r}$. festynu z okazji 25-lecia istnienia firmy Bieber. Podczas tej uroczystości urzędnikom i pracownikom wypłacono sumę 10 tys. marek ${ }^{23}$. W tym czasie, jak podaje „Thorner Presse”: „Die Firma steht mit dem Auslande in Geschäftsverbindung und ist in weiten Kreisen bekannt. [...] erfreut sich bei den Gemeindeeingesessenen grosser Achtung und Verehrung"24. W 1914 r. w firmie H. Bieber w Przechowie pracowało 105 robotników, zarówno Polaków, jak i Niemców ${ }^{25}$. Nie zawsze jednak relacje między pracownikami a właścicielem układały się pomyślnie. We wrześniu 1913 r. grupa 65 robotników pracujących w młynie ogłosiła strajk, żądając poprawy warunków pracy i wzrostu wynagrodzenia ${ }^{26}$. Po I wojnie światowej wartość majątku Biebera wciąż była ogromna, a sam Kommerzienrat Bieber w 1919 r. z okazji swoich 75 urodzin wsparł kwotą 100 tys. ma-

${ }^{20}$ Ernst Seyfert, Güter-Adreßbuch für die Provinz Westpreussen, Leipzig 1912, s. 182-183. Zob. także Handbuch des Grundbesitzes im Deutschen Reiche. Provinz Westpreussen. Im Auftrag der Landwirtschaftskammer unter Mitwirkung der Königlichen Behörden der Provinz, Berlin 1909, s. 276-277.

${ }^{21}$ Kazimierz WajDA, Świecie i powiat świecki w czasach zaboru pruskiego, [in:] Dzieje Świecia i jego regionu, t. 1, red. Kazimierz JAsı́́ski, Warszawa-Poznań-Toruń 1979, s. 312. Młyny w Przechowie pełniły ważną funkcję gospodarczą nie tylko na rynku lokalnym (powiat świecki), czego dowodzą stosunki handlowe z Berlinem w latach siedemdziesiątych XIX w. Zob. Gustav Gerlich, Statistische Beschreibung des Schwetzer Kreises, Schwetz 1878, s. 58; Hugo Rasmus, op.cit., s. 12. Majątek J. Biebera nie ograniczał się do Przechowa. W 1904 r. „Gazeta Toruńska” informowała: „Młyn i posiadłość w Kozłowie pod Terespolem nabył od p. Raczyńskiego z Szarlotenburga p. Bieber z Przechowa za 88800 marek"; Gazeta Toruńska, 1904, nr 231, s. 2. Co interesujące, nabyty przez Biebera majątek w Kozłowie (w tym 325 ha ziemi ornej i ogrodów oraz 21 ha łąk) znacznie przekraczał pod względem wielkości jego majątek w Przechowie (82 ha). Zob. Handbuch des Grundbesitzes im Deutschen Reiche. Provinz Westpreussen, s. 272-273, 276-277.

${ }^{22}$ K. WAJDA, op.cit., s. 312.

${ }^{23}$ Gazeta Toruńska, 1897, nr 218, s. 2-3; Thorner Presse, 1897, nr 220, s. 5.

${ }^{24}$ Thorner Presse, 1897, nr 220, s. 5.

${ }^{25}$ K. WAJDA, op.cit., s. 312.

${ }^{26}$ Jak podaje „Gazeta Toruńska”, polscy i niemieccy pracownicy firmy Bieber zażądali m.in. zwiększenia dziennego wynagrodzenia o 30 fenigów. Zaostrzenie konfliktu doprowadziło do zapowiedzi właściciela na temat masowych zwolnień i sprowadzenia „robotników z Hamburga”. Zob. Gazeta Toruńska, 1913, nr 217, s. 1; Gazeta Toruńska, 1913, nr 221, s. 1. 
rek nowo powstały żłobek powiatowy w Świeciu ${ }^{27}$. We wrześniu 1921 r., już po zmianie granic i włączeniu powiatu świeckiego do Polski, J. Bieber zdecydował się sprzedać - jak podaje „Słowo Pomorskie” - „największy młyn na Pomorzu "Przechowo»" za kwotę bagatela $85 \mathrm{mln}$. marek polskich ${ }^{28}$. Niewątpliwie była to wysoka kwota (po przeliczeniu na dolary amerykańskie), która pozwoliła J. Bieberowi oraz jego żonie na dostatnie życie w Berlinie ${ }^{29}$, do którego się udali ${ }^{30}$.

„Słowo Pomorskie” donosiło, że firma (spółka jawna) Heinrich Bieber przestała istnieć 23 IX 1921 r., a nabywcami byli Polacy, mieszkańcy Wętfi Kazimierz Jakubowski i Leon Piotrowski ${ }^{31}$. Warto jednak podkreślić, że majątek Biebera został wykupiony przez Towarzystwo Akcyjne firmy „Przechowo Młyny i Tartaki”32, w czym finansowo dopomógł Bank M. Stadthagen z Byd-

${ }^{27}$ Jahresberichte der preussischen Regierungs- und Gewerberäte und Bergbehörden, 19141918, Berlin 1919, s. 64; Księga pamiątkowa dziesięciolecia Pomorza 1920-1930, red. Kazimierz Esden-Tempski, Marian Sydow, Toruń 1930, s. 416.

${ }^{28}$ Słowo Pomorskie, 1921, nr 224, s. 4. Kwotę $85 \mathrm{mln}$ marek polskich potwierdza także raport polityczny Ekspozytury Oddziału Informacyjnego Okręgu Generalnego Pomorze w Chojnicach z dnia 1 X 1921 r., w którym jest mowa o wykupieniu „najważniejszych młynów na Pomorzu - Przechowo"; Centralne Archiwum Wojskowe Warszawa-Rembertów, Dowództwo Okręgu Korpusu nr VIII, sygn. I. 371.8/A 74.

${ }^{29}$ Lidia Smentek podaje, że sprzedaż majątku okazała się wysoce nieopłacalna dla J. Biebera, a on sam „na drugi dzień mógł za wszystkie pieniądze kupić parę butów”; L. SMENTEK, op.cit., s. 32. Opinia ta wydaje się mylna, ponieważ inflacja trwała już od końca 1918 r., a procesy inflacyjne przyspieszyły dopiero w latach 1922-1923. Zob. Zbigniew LandaU, Jerzy ToMASZewski, Gospodarka Polski międzywojennej 1918-1939, t. 1: W dobie inflacji 1918-1923, Warszawa 1967, s. 280-281; Aleksandra FARON, Przebieg inflacji markowej w II Rzeczypospolitej, Studia Ekonomiczne, t. 26: 2003, s. 42. Jacob Bieber, doświadczony przedsiębiorca obeznany w sprawach finansowych, mając w planach wyjazd do Berlina, z pewnością zdecydował się na szybkie przewalutowanie kwoty transakcji z marek polskich na dolary lub marki niemieckie. Jeszcze w 1922 r., czyli już po sprzedaży młynów, jest on potwierdzony jako członek rady nadzorczej Towarzystwa Akcyjnego „Przechowo Młyny i Tartaki”. Zob. Spółki akcyjne w Polsce, R. 2, red. Roman Urban, Bronisław Wietrzy Kowski, Poznań 1922/1923, s. 103.

${ }^{30} \mathrm{Na}$ temat sytuacji prawnej optantów niemieckich i ruchu migracyjnego ludności niemieckiej z Pomorza do Rzeszy w 1921 r. zob. Marek StażEwsKi, Exodus. Migracja ludności niemieckiej z Pomorza do Rzeszy po I wojnie światowej, Gdańsk 1998, s. 170-195.

${ }^{31}$ Słowo Pomorskie, 1921, nr 224, s. 4, 6.

${ }^{32}$ Spółki akcyjne w Polsce, R. 1, red. Roman Urban, Bronisław Wietrzykowski, Poznań 1921/1922, s. 100; Dziennik Bydgoski, 1921, nr 226, s. 4. W latach dwudziestych XX w. Towarzystwo zarządzało majątkiem o powierzchni $70 \mathrm{ha,} \mathrm{w} \mathrm{tym} \mathrm{młynami} \mathrm{wodnymi} \mathrm{i} \mathrm{tartakami.} \mathrm{Wła-}$ ścicielem drugiego majątku o podobnej wielkości w Przechowie był Hugo Kuchenbecker. Zob. Książka adresowa gospodarstw rolnych ponad 50 hektarów wojew. pomorskiego, opr. Stanisław Manthey, Toruń 1923, s. 356-357; Ksiega adresowa gospodarstw rolnych ponad 50 hektarów województwa pomorskiego, opr. Stanisław MANTHEY, Toruń 1929, s. 540-541; Ksiega adresowa Polski (wraz z w. m. Gdańskiem) dla handlu, przemystu, rzemiosł i rolnictwa, Bydgoszcz 1927-1930, s. 1189, 1204-1205. W drugiej połowie 1929 r. młyny w Przechowie „odznaczały się ogromną 
goszczy $^{33}$. Sama transakcja zmiany właściciela młynów w Przechowie zapewne była przygotowywana dużo wcześniej, ponieważ wspomniane Towarzystwo zostało utworzone już w 1920 r., a sam J. Bieber zasiadał w jego radzie nadzorczej jeszcze w roku $1922^{34}$. Można zatem wnioskować, że były właściciel młynów jako członek rady nadzorczej, a co za tym idzie - akcjonariusz Towarzystwa, zabezpieczył swoje dochody także po zmianie własnościowej i likwidacji spółki jawnej H. Bieber ${ }^{35}$.

Przez długi czas majątek rodziny i dochody firmy Bieber pozwalały na wsparcie finansowe edukacji Margarete. Od samego początku rodzice byli w stanie zapewnić jej solidne wykształcenie w duchu protestanckim. W młodości uczyła się w domu, a lekcji udzielała jej guwernantka ${ }^{36}$. Następnie uczęszczała do miejscowej szkoły dla dziewcząt (Töchterschule) w Przechowie. W latach 1893-1895 w szkole z internatem dla dziewcząt w Dreźnie przyszła uczona pobierała nauki nie tylko z języka francuskiego, angielskiego, geografii czy historii sztuki i literatury, lecz także z malunku, tańca i gry na fortepianie $^{37}$. W 1899 r. w Berlinie dwudziestoletnia Margarete odbyła roczny kurs przygotowujący do matury, gdzie uczyła się pod kierunkiem Heleny Lange (1848-1930), słynnej niemieckiej pedagog i aktywistki walczącej o prawa kobiet $^{38}$. W tym okresie nauczycielką filozofii i języka niemieckiego Bieber była inna emancypantka, Hildegard Wegscheider (1871-1953), która jako jedna z pierwszych w historii kobiet w 1898 r. uzyskała stopień doktora nauk humanistycznych (Dr. Phil.) na Uniwersytecie w Halle ${ }^{39}$. Niewątpliwie te dwie poli-

zdolnością przemiału” i były trzecim największym na Pomorzu Gdańskim producentem mąki, zatrudniającym 60 pracowników. Zob. Zbigniew Kuras, Przemyst na Pomorzu Gdańskim w latach 1920-1939, Bydgoszcz 1984, s. 21-22.

${ }^{33}$ Zob. Monograficzny almanach polskiego handlu i przemysłu, Bydgoszcz 1923, s. 8.

${ }^{34}$ Spółki akcyjne w Polsce, R. 1, s. 100; Spółki akcyjne w Polsce, R. 2, s. 103. Z kolei członkiem zarządu był E. Bieber, zapewne syn właściciela młynów.

${ }^{35}$ W 1927 r. członkowie rodziny Bieber nie zasiadali już w radzie nadzorczej i zarządzie Towarzystwa Akcyjnego. W tym czasie funkcję prezesa sprawował K. Różycki. Zob. Spółki akcyjne w Polsce, R. 3, red. Roman Urban, Poznań-Warszawa 1928, s. 113-114.

${ }^{36}$ Matthias Recke podkreślił, że Margarete odebrała „christliche-säkulare Erziehung”; M. Recke, Bieber, Margarete, col. 103. Zob także H. P. ObermaYer, op.cit., s. 40.

${ }^{37}$ H.-G. Buchiolz, op.cit., s. 58.

${ }^{38}$ M. Recke, Bieber, Margarete, col. 103. Na temat działalności Lange i jej zaangażowania w prace nad reformą średniego szkolnictwa żeńskiego w Niemczech zob. Aneta NiEwĘGŁowSKA, Średnie szkolnictwo żeńskie w Prusach Zachodnich w latach 1815-1914, Toruń 2014, s. 116.

${ }^{39}$ Hildegard Wegscheider-Zieglers, Chronicon Carionis. Ein Beitrag zur Geschichtsschreibung des 16. Jahrhunderts, Halle 1898. Pierwszą Niemką, która w 1754 r. otrzymała stopień doktora medycyny, była Dorothea Erxleben. Drugą natomiast była Maria von Linden, która w 1895 r. obroniła doktorat w Tybindze. Zob. Patricia M. Mazón, Gender and the Modern Research University: The Admission of Women to German Higher Education, 1865-1914, Stanford 2003, s. 180 . 
tycznie zaangażowane kobiety wywarły silny wpływ na postawę życiową i edukacyjną młodej Margarete ${ }^{40}$. Rodzina namawiała córkę, by swą drogę edukacyjną, a co za tym idzie - zawodową, związała z medycyną ${ }^{41}$, jednak ta chciała zostać nauczycielką. Najbardziej interesowały ją bowiem nauki humanistyczne, zwłaszcza zaś kultura starożytna.

Po zdaniu matury w 1901 r. w Toruniu ${ }^{42}$ Bieber zdecydowała się rozpocząć studia w zakresie szeroko rozumianej nauki o starożytności (Altertumswissenschaft) na Uniwersytecie w Berlinie ${ }^{43}$. Tam w latach 1901-1904 pochodząca z Przechowa przyszła uczona studiowała historię starożytną, filozofię oraz filologię. Była uczennicą m.in. dwóch wybitnych filologów klasycznych: pochodzącego z Markowic (gmina Strzelno) Ulricha von Wilamowitz-Moellendorffa (1848-1931) ${ }^{44}$ oraz Hermanna Aleksandra Dielsa (1848-1922), jak też wybitnego historyka starożytności Eduarda Meyera (1855-1930). W 1904 r. M. Bieber przeniosła się do Bonn, gdzie koncentrując się na sztuce antycznej, uczyła się pod kierunkiem innych cenionych badaczy, m.in. arche-

${ }^{40}$ M. Recke, „...besonders schauerlich war die Anwesenheit von Frl. Bieber”, s. 212.

${ }^{41}$ H.-G. BuchHolz, op.cit., s. 58. Nie bez znaczenia jest to, że żydowscy absolwenci gimnazjum toruńskiego najczęściej decydowali się właśnie na studia medyczne oraz prawnicze. Zob. Krystyna KęPczyńska, Absolwenci Gimnazjum Toruńskiego w drugiej połowie XIX i na początku XX wieku, Acta Universitatis Nicolai Copernici. Historia XI, z. 74, 1977, s. 126. Zob. także Lucjan Broniewicz, Tworzenie się inteligencji żydowskiej w Prusach Zachodnich. Żydowscy absolwenci gimnazjów przed 1914 rokiem, [in:] Emancypacja - asymilacja - antysemityzm. Żydzi na Pomorzu w XIX i XX wieku, red. Zenon Hubert Nowak, Toruń 1992, s. 35-37.

${ }^{42}$ Tę informację można przeczytać w Lebenslauf badaczki, załączonym na końcu jej doktoratu. Zob. Margarete BIEBER, Das Dresdener Schauspielerrelief. Ein Beitrag zur Geschichte des tragischen Costüms und der Griechischen Kunst (dysertacja doktorska, Universität Bonn), Bonn 1907, s. 92. Bieber nie została zapisana na listach abiturientów gimnazjum toruńskiego, publikowanych w corocznych sprawozdaniach. Zob. Königliches Gymnasium mit Realgymnasium zu Thorn. Bericht über das Schuljahr 1900/1901, Thorn 1901, s. 28; Königliches Gymnasium mit Realgymnasium zu Thorn. Bericht über das Schuljahr 1901/1902, Thorn 1902, s. 28. Fakt ten można tłumaczyć tym, że uzyskała ona maturę eksternistycznie, przygotowując się do niej od 1899 r. w Berlinie. Dlatego też nie można jej określić sensu stricto absolwentką toruńskiego gimnazjum. W tym czasie nie mogła ona bowiem uczęszczać do męskiej szkoły wyższej. W Prusach dopiero na mocy reformy szkolnictwa żeńskiego z 1908 r. powstały dziesięcioklasowe wyższe szkoły żeńskie, a kobiety uzyskały prawo do zdawania egzaminów maturalnych i studiowania. Zob. Aneta NiewęGŁowska, Średnie szkolnictwo żeńskie w Toruniu $w$ latach 1820-1920, Rocznik Toruński, t. 31: 2004, s. 119-121. Krystyna Podlaszewska wprawdzie odnotowuje uzyskanie przez M. Bieber matury w 1901 r., jednak nie podaje źródła tej informacji; K. PodLAszewsKA, op.cit., s. 180, przyp. 55; por. L. SMENTEK, op.cit., s. 39-45.

${ }^{43}$ Absolwenci gimnazjum toruńskiego najczęściej wybierali studia na uniwersytetach w Berlinie, we Wrocławiu, w Lipsku i Królewcu. Zob. K. KęPczyńsKa, op.cit., s. 123; K. PodLASZEWSKA, op.cit., s. 170.

${ }^{44}$ Szerzej na temat tego wybitnego filologa klasycznego pochodzącego z Markowic na Kujawach zob. Ulrich von Wilamowitz-Moellendorff i jego mała ojczyzna. W osiemdziesiąta rocznicę śmierci wielkiego Kujawianina, red. Włodzimierz Appel, Strzelno 2013. 
ologa Georga Loeschckego (1852-1915) oraz historyka sztuki Paula Clemena (1866-1947). Szczególny wpływ na metodę badań M. Biebier wywarł właśnie Georg Loeschcke ${ }^{45}$. W 1907 r. na Uniwersytecie w Bonn pod jego kierunkiem, w wieku 28 lat, obroniła doktorat poświęcony dziejom kostiumu tragicznego w sztuce greckiej ${ }^{46}$.

Nie od razu jednak związała się z akademią. Dzięki wsparciu finansowemu rodziny wiele podróżowała, zwiedzając m.in. Włochy, Grecję oraz Turcję. Początkowo rozwijała swe zainteresowania badawcze, realizując stypendia i pracując w różnego rodzaju instytucjach naukowych. Działała m.in. jako asystent archeologiczny w Niemieckim Instytucie Archeologicznym w Atenach oraz jako asystentka w Muzeum w Kassel, gdzie opracowała katalog rzeźb antycznych przechowywanych $w$ tym muzeum ${ }^{47}$. Po wybuchu I wojny światowej w 1914 r. Margarete wróciła do swojej rodzinnej miejscowości, gdzie wspólnie z siostrą Anną niosły pomoc w ramach Czerwonego Krzyża ${ }^{48}$. W 1915 r. pojechała do Berlina, gdzie do 1916 r. pracowała w DAI. Do 1918 r. jako asystentka prof. Loeschkego prowadziła także zajęcia ze studentami. Jednym z nich był Erwin Panofsky (1892-1968), twórca teorii interpretacji ikonologicznej.

W 1919 r. rozpoczęła zawodową karierę akademicką, co stało się możliwe dzięki liberalizacji podejścia Republiki Weimarskiej do zatrudniania kobiet na uczelniach ${ }^{49}$. Jako uczona zajmująca się sztuką, a także teatrem antycznym, któremu w 1919 r. poświęciła swą rozprawę pt. Die Denkmäler zum Theaterwesen im Altertum, została "wykładowczynią bez pensji" (Privatdozentin ohne Gehalt) na Uniwersytecie w Gießen ${ }^{50}$. W tym czasie była jedyną kobietą-wykładowcą na wydziale archeologicznym. Nie otrzymywała żadnego wynagrodzenia, dlatego rodzina wciąż wspierała ją finansowo ${ }^{51}$. W 1923 r., w wieku 44 lat, M. Bieber awansowała na stanowisko profesora nadzwyczajnego i kierownika katedry archeologii. W 1932 r. spodziewała się otrzymania profesury zwyczajnej, jednak jej kariera naukowa została wstrzymana przez zmieniającą się sytuację polityczną w Niemczech. Od stycznia do kwietnia 1933 r. na

${ }^{45}$ M. RECKE, „...besonders schauerlich war die Anwesenheit von Frl. Bieber”, s. 213.

${ }^{46}$ Zob. przyp. 42.

${ }^{47}$ Margarete BIEBer, Die antiken Sculpturen und Bronzen des königlichen Museums Fridericianum in Cassel, Marburg 1915.

${ }^{48} \mathrm{~W}$ kwietniu $1915 \mathrm{r}$. „Thorner Presse” donosił o wsparciu finansowym rodziny Bieber z Schönau udzielonym niemieckim jeńcom wojennym. Zob. Thorner Presse, 1915, nr 99, s. 5: „Die Familie des Kommerzienrats Bieber in Schönau spendete für kriegsgefangene Deutsche in Feindesland 600 Mark".

${ }^{49}$ L. Bonfante, Margarete Bieber (1879-1978): An Archaeologist in Two Worlds, s. 249.

${ }^{50}$ Wykład habilitacyjny Bieber dotyczył ubioru kobiet w starożytnej Grecji; H.-G. BucHHOLZ, op.cit., s. 62.

${ }^{51}$ H. P. Freidenreich, op.cit., s. 74. 
skutek polityki narodowosocjalistycznej osoby pochodzenia żydowskiego były zmuszane do opuszczenia stanowisk akademickich ${ }^{52}$. Mimo przyjęcia przez M. Bieber wyznania starokatolickiego w 1920 r. (jej najbliższa rodzina wyznawała protestantyzm ${ }^{53}$ ) również ona musiała opuścić mury akademii ${ }^{54}$. Przez długi czas wybitna uczona prezentowała postawę typową dla Żydów pochodzących z niemieckich kresów wschodnich, którzy szczególnie chętnie przyjmowali niemieckie wzorce kulturowe ${ }^{55}$. Później natomiast, wskutek antysemickiej ideologii hitlerowskich Niemiec i emigracji do Stanów Zjednoczonych, zmieniła swoje nastawienie. Po latach, będąc już na emigracji, pisała: „I am not a Jew and do not consider myself as a Jew. Until now I have considered myself German. I believe, however, that in the sense of the citizenship law, I am a Jew. I will in any case soon no longer be a German, but after 1940 a proud citizen of the free land of America"56.

W 1933 r. wybitna historyk sztuki wraz ze swoją adoptowaną córką Ingebord (M. Bieber nigdy nie wyszła za mąż) oraz gospodynią domową (pielęgniarką) Kathariną Freytag wyemigrowała do Anglii ${ }^{57}$. W Oksfordzie została członkiem honorowym Somerville College. Następnie na zaproszenie Barnard College wyjechała do Stanów Zjednoczonych i w 1936 r. objęła stanowisko visiting professor na Uniwersytecie Columbia ${ }^{58}$. Rok później została mianowana profesorem sztuk pięknych i archeologii. Duże znaczenie dla starań uczonej o pobyt za granica i pracę na amerykańskiej uczelni miała rekomendacja wybitnego badacza historii gospodarczej antyku - Michaiła Rostovtzeffa (1870-1952) z Yale University ${ }^{59}$.

52 Ibid., s. 167.

${ }^{53}$ H. P. Obermayer, op.cit., s. 40, przyp. 22.

${ }^{54} \mathrm{~W}$ akcie urodzenia M. Bieber została przypisana do wyznania mojżeszowego (mosaischer religion); Archiwum Państwowe w Bydgoszczy, USC w Przechowie, sygn. 6/1763/0/2.1/32, nr 34. Jeszcze w 1907 r. M. Bieber pisała: „Ich bin israelitischer Religion”. Zob. M. Bieber, Das Dresdener Schauspielerrelief, s. 92. Niewykluczone, że w jej przypadku konwersja była motywowana chęcią uniknięcia dyskryminacji kobiet pochodzenia żydowskiego na uczelniach. Pochodzenie żydowskie utrudniało bowiem karierę akademicką. Wstąpienie M. Bieber do Kościoła starokatolickiego w 1920 r. zbiegło się w czasie z oficjalną zgodą Republiki Weimarskiej na możliwość objęcia przez kobiety profesury akademickiej. Zob. H. P. Freidenreich, op.cit., s. 73: "The majority of the women who gained Habilitation status can be classified as «Former Jews», however, since they had either been baptized as children or had subsequently left the Jewish community".

${ }^{55}$ Szerzej zob. Max Aschкewitz, Zur Geschichte der Juden in Westpreussen, Marburg/Lahn 1967; L. BroniewiCZ, op.cit., s. 28-30; Z. KARPUs, op.cit., s. 109.

${ }^{56}$ Cyt. za: H. P. Freidenreich, op.cit., s. 167.

${ }^{57}$ Szerzej zob. ibid., s. 131, 137.

${ }^{58}$ Szerzej na temat okresu emigracyjnego w życiu uczonej zob. H. P. OBERMAYer, op.cit., s. $35-107$.

${ }^{59}$ Ibid., s. $46-47$. 
Choć w 1946 r. Bieber, w wieku 67 lat, przeszła na emeryturę ${ }^{60}$, to wciąż była czynna naukowo. Wykładała m.in. na Uniwersytecie Princeton, na którym działali także inni niemieccy imigranci: historyk sztuki Erwin Panofsky i bizantynolog Kurt Weitzmann ${ }^{61}$. Uczona wykształciła godnych siebie następców, uznanych historyków sztuki starożytnej - Evelyn Byrd Harrison oraz Larissę Bonfante, która poświęciła swojej nauczycielce liczne studia ${ }^{62}$. Choć w Stanach Zjednoczonych antysemityzm był zabroniony, to jednak na uniwersytetach podejście do amerykańskich uczonych żydowskiego pochodzenia, tak samo jak do kobiet-uczonych, nie było jednakowe. William M. Calder III zilustrował ograniczenia, z jakimi spotykali ci uczeni, właśnie przykładem Bieber: „Margarete Bieber do końca pozostawała profesorem nadzwyczajnym, a odchodząc na emeryturę [...] nie otrzymała tytułu professor emeritus" ${ }^{63}$.

Margarete Bieber otrzymała liczne nagrody i wyróżnienia naukowe. W Bonn w 1957 r., czyli w 50 rocznicę obrony rozprawy doktorskiej, odbyła się uroczysta odnowa jej doktoratu, a w 1954 r. Uniwersytet Columbia przyznał jej tytuł Doctor of Literature (honoris causa), natomiast rok później w prestiżowej serii Columbia Bicentennial Editions and Studies została ponownie wydana jej dawna, lecz wciąż aktualna praca pt. The Sculpture of the Hellenistic Age ${ }^{64}$. W 1974 r. Amerykański Instytut Archeologiczny przyznał jej złoty medal za wybitne osiągnięcia naukowe.

Margarete Bieber była uznaną badaczką, często cytowaną na całym świe$\mathrm{cie}^{65}$. Współcześni historycy sztuki podkreślają umiejętność łączenia przez nią niemieckiego, XIX-wiecznego, stricte naukowego i przez to nieco hermetycznego podejścia do sztuki antycznej $\mathrm{z}$ amerykańskim pragmatyzmem naukowym, pozwalającym na dotarcie do szerszego kręgu odbiorców ${ }^{66}$. Jej często interdyscyplinarne badania nie ograniczały się do wąsko zakreślonej problematyki czy tylko jednego okresu w dziejach starożytnych (np. epoki hellenistycznej). Bieber, dysponując wszechstronnym warsztatem naukowym oraz doświadczeniem badawczym historyka sztuki i archeologa, potrafiła analizo-

${ }^{60}$ H.-G. BuchHolz, op.cit., s. 69.

${ }^{61}$ Ibid., s. 69.

${ }^{62}$ Zob. przyp. 11.

${ }^{63}$ William M. Calder III, Filologia klasyczna w Ameryce, Meander. Miesięcznik poświęcony kulturze świata starożytnego, R. 49: 1994, nr 7-8, s. 393.

${ }^{64}$ H. P. Obermayer, op.cit., s. 107.

${ }^{65}$ Jej prace, zwłaszcza monografię poświęconą greckiemu i rzymskiemu teatrowi oraz hasła w Realencyclopädie der classischen Altertumswissenschaft poświęcone zagadnieniom teatru, przywoływali także polscy uczeni. Zob. np. Stefan Srebrny, Teatr grecki i polski, Warszawa 1984, s. 760; Mirosław Kocur, Teatr antycznej Grecji, Wrocław 2001, s. 188, 249; Agnieszka KotLiŃSкA-Toma, Tragedia hellenistyczna, Wrocław 2006, s. 221.

${ }^{66}$ Larissa Bonfante, Bieber, Margarete (1879-1978), [in:] Encyclopedia of the History of Classical Archaeology, ed. Nancy Thomson de Grummond, New York 1996, s. 159-160. 
wać i opisywać sztukę nie tylko Grecji archaicznej, lecz także cesarskiego Rzymu. Szczególnie ważne dla dyskursu naukowego, jak wynika z analiz historiograficznych Clifforda Asby’ego, były jej studia dotyczące historii greckiego teatru klasycznego ${ }^{67}$. W 1939 r. M. Bieber opublikowała syntezę dziejów teatru greckiego okresu archaicznego, klasycznego i hellenistycznego oraz rzymskiego w epoce republiki i cesarstwa pt. The History of the Greek and Roman Theater (drugie wyd. w 1961 r.), opracowaną zarówno na podstawie źródeł archeologicznych, ikonograficznych, jak i narracyjnych. W pracy tej postawiła nie tylko ważną hipotezę na temat swego rodzaju ciągłości dwóch typów przedstawień teatralnych (komedii i dramatu) aż do III w. n.e. ${ }^{68}$, lecz także, porównując np. dramat satyrowy z grami czy raczej obrzędami mieszkańców wyspy Bali podczas festiwali religijnych, przekraczała ramy tradycyjnego warsztatu naukowego w zakresie badań nad sztuką grecko-rzymską, wypracowywane od czasów Johanna J. Winckelmanna $(1717-1768)^{69}$. W 1928 r. wybitna uczona wydała pracę pt. Griechische Kleidung, w której na podstawie bogatego materiału ikonograficznego (głównie greckich waz i terakoty) analizowała strój grecki, zwłaszcza noszony przez kobiety peplos oraz najbardziej charakterystyczny strój męski i damski - chiton. W późniejszym czasie w kręgu jej zainteresowań znalazł się także strój rzymski analizowany na tle porównawczym ${ }^{70}$. Bieber napisała także ważne prace poświęcone sztuce greckiej okresu hellenistycznego, w tym monografię jednej z najsłynniejszych rzeźb, tzw. Grupy Laokoona i jej wpływu na sztukę ${ }^{71}$. Wreszcie zaś była autorką studium poświęconego historii rzeźby greckiej w tym okresie (The Sculpture of the Hellenistic Age, Columbia 1955). Z kolei jedną z jej najważniejszych prac, wynikiem długoletnich studiów, było studium pt. Alexander the Great in Greek and Roman Art (Chicago 1964). Bieber planowała także wydać monografię na temat portretów bitych na monetach antycznych. Cząstkowe wyniki swoich badań w tym względzie w odniesieniu do epoki republiki rzymskiej opublikowała w prestiżowej serii Aufstieg und Niedergang der römischen Welt ${ }^{72}$. Miała również zamiar napisać syntezę na temat stroju antycznego, jednak pracy tej nie ukończyła. Uczoną in-

${ }^{67}$ Clifford Ashry, Classical Greek Theatre: New Views of an Old Subject, Iowa 1999, s. 139-146 (rozdział pt. Validation by Authority: Margarete Bieber's Comparisons of Hellenistic and Roman Theatres).

${ }^{68}$ Margarete BIEBER, The History of the Greek and Roman Theater, Princeton 1961, s. $227-253$.

${ }^{69}$ Ibid., s. 17. Zob. C. Ashby, op.cit., s. 139.

${ }^{70}$ Margarete BIEBER, Charakter und Unterscheide der griechischen und römischen Kleidung, Archäologischer Anzeiger, 1973, s. 425-447.

${ }^{71}$ Eadem, Laocoon: The Influence of the Group since its Rediscovery, Columbia 1942.

${ }^{72}$ Eadem, The Development of Portraiture on Roman Republican Coins, [in:] Aufstieg und Niedergang der römischen Welt. Rise and Decline of the Roman World, vol. 4/1, ed. Hildegard Temporini, Wolfgang HaAse, Berlin-New York 1973, s. 871-898. 
teresowały także zagadnienia z zakresu architektury rzymskiej epoki wczesnego cesarstwa. Opublikowała m.in. wnikliwą recenzję monografii poświęconej kolumnie Marka Aureliusza w Rzymie ${ }^{73}$.

Wybitna historyk sztuki i archeolog była nie tylko aktywną uczoną, zasłużoną dla nauki niemieckiej i amerykańskiej, lecz także zaangażowanym dydaktykiem. Dla anglojęzycznych studentów germanistyki oraz historii sztuki zainteresowanych niemieckimi badaniami nad sztuką antyczną Bieber przygotowała opracowanie pt. German Readings in the History and Theory of Fine Arts, vol. I: Greek and Roman Art (New York 1946). Pisane przez nią prace, jak sama podkreślała, miały być dostępne nie tylko dla specjalistów, badaczy sztuki antycznej, lecz także dla studentów i czytelników szerzej zainteresowanych kulturą antyczną ${ }^{74}$.

W 1977 r. pochodząca z Prus Zachodnich uczona opublikowała swoją ostatnią książkę pt. Ancient Copies: Contributions to the History of Greek and Roman Art, która stanowiła - jak podkreśliła w recenzji Holly Lee Schanz - realizację wcześniejszych planów uczonej ${ }^{75}$. W tym cennym opracowaniu Bieber, skupiając się głównie na analizie greckiego stroju, badała to, jak rzymscy artyści tworzyli kopie rzeźb greckich. W ciągu 70 lat, od 1907 r. - momentu wydania doktoratu - aż do 1977 r., czyli czasu wydania ostatniej swojej monografii, M. Bieber opublikowała 350 prac dotyczących głównie historii teatru antycznego i stroju greckiego ${ }^{76}$. Margarete Bieber zmarła w 1978 r. w New Canaan (w stanie Connecticut), w wieku 99 lat ${ }^{77}$.

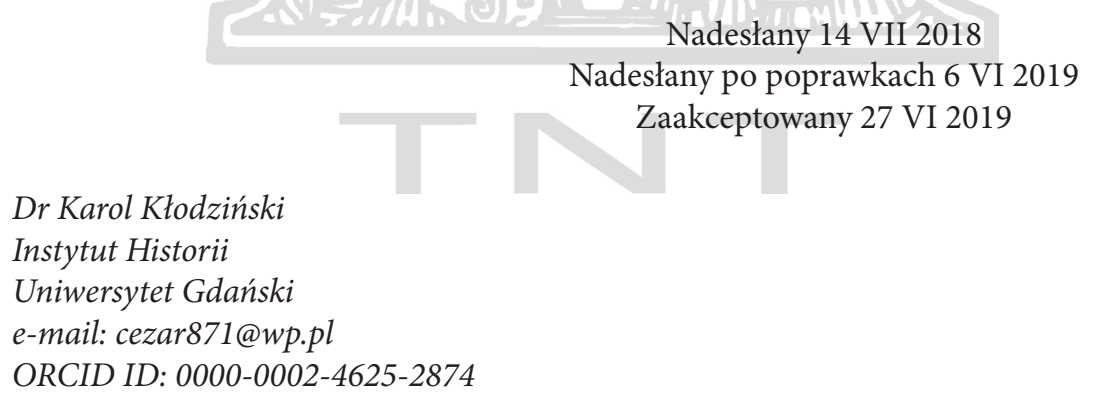

${ }^{73}$ Eadem, rec.: Giovanni Becatti, Colonna di Marco Aurelio, Milan 1957, American Journal of Archaeology, vol. 63: 1959, no. 1, s. 107-108.

${ }^{74}$ M. BIEBER, Laocoon, s. 5.

${ }^{75}$ Holly Lee Schanz, rec.: M. Bieber, Ancient Copies: Contributions to the History of Greek and Roman Art, New York 1977, The Art Bulletin, vol. 62: 1980, no. 2, s. 307-309.

${ }^{76}$ H.-G. Buchiolz, op.cit., s. 71.

${ }^{77}$ Swego czasu zapytana o receptę na długowieczność M. Bieber odpowiedziała: „Richtige Ernährung und Veranlagung, mein Urgrossvater wurde 102, mein Vater 93 Jahre alt". Cyt. za: ibid., s. 70 . 


\title{
Margarete Bieber (1879-1978): Eminent Classical Scholar From Western PrUssia
}

\begin{abstract}
Keywords: Przechowo, women's emancipation, ancient culture, classical archaeology, women of science

The article presents the biography and scientific achievements of the outstanding researcher of ancient culture, Margarete Bieber (1879-1978). At the same time, it is an example of women's emancipatory aspirations in this region at the turn of the $19^{\text {th }}$ and $20^{\text {th }}$ centuries. The article describes the less-known Pomeranian roots of Margarete Bieber. She came from Przechów (Schönau, Świecie district) in former Western Prussia. Bieber was the first woman from Western Prussia to pass high school final examinations in Torun in 1901. Then, despite all kinds of difficulties arising from her gender and ethnicity, she made an excellent academic career in Germany and the United States.

The article also describes in detail the Pomeranian Bieber family living in Przechów and their property status (until the sale of the mills in 1921). Jacob Bieber, Margarete's father, the owner of "the most important mills in Pomerania - Przechowo", who perhaps was interested in ancient art himself, supported the scholar's research for a long time. The high financial and social status of the family was important for her educational opportunities, but it was not recognized in the article as the most important reason for her success. First of all, her personality features, talent and great diligence were emphasized.
\end{abstract}

\section{Margarete Bieber (1879-1978), EINE BEdEUTENDE ANTIKENForscherin AUS WESTPREUSSEN}

\begin{abstract}
Schlüsselwörter: Schönau in Westpreußen, Frauenemanzipation, antike Kultur, klassische Archäologie, Frauen der Wissenschaft

In dem Artikel geht es um die Biografie und die wissenschaftlichen Leistungen der bedeutenden Antikenforscherin Margarete Bieber (1879-1978). Zugleich handelt es sich dabei um ein Beispiel für die emanzipatorischen Bestrebungen von Frauen in dieser Regions an der Wende vom 19. zum 20. Jahrhundert. Der Artikel beschreibt die bisher wenig bekannten Wurzeln von Margarete Bieber in Pommern. Sie stammte aus Schönau (Przechowo, einem Stadtteil von Schwetz) auf dem Gebiet des früheren Westpreußens. Als erste Frau aus Westpreußen legte sie 1901 in Thorn das Abitur ab. Danach machte sie eine großartige akademische Karriere in Deutschland und den USA, trotz Schwierigkeiten verschiedener Art, die aus ihrerm Geschlecht und ihrer ethnischen Zugehörigkeit herrührten.
\end{abstract}


Der Artikel besschreibt auch ausführlich die pommersche Familie Bieber, die in Schönau wohnte, und ihren Vermögensstatus (bis zum Verkauf der Mühlen 1921). Jacob Bieber, der Vater von Margarete und Eigentümer der „wichtigsten Mühlen in Pommern, in Schönau“, der sich möglicherweise selbst für antike Kunt interessierte, unterstützte lange Zeit die Forschungen der Gelehrten. Die hohe finanzielle und gesellschaftliche Position der Familie war von Bedeutung für ihre Ausbildungsmöglichkeiten, wird aber in dem Artikel nicht als die Hauptursache ihrer Erfolge angesehen. Hervorgehoben werden vor allem die Bedeutung ihrer charakterlichen Eigenschaften, ihr Talent und ihr Fleiß.

\section{BIBLIOGRAFIA ${ }^{78}$}

Appel, Włodzimierz, ed. Ulrich von Wilamowitz-Moellendorff i jego mała ojczyzna. W osiemdziesiąta rocznice śmierci wielkiego Kujawianina. Strzelno: Polskie Towarzystwo Historyczne. Koło w Strzelnie, 2013.

Aschkewitz, Max. Zur Geschichte der Juden in Westpreussen. Marburg/Lahn: Johann Gottfried Herder-Institut, 1967.

Ashby, Clifford. Classical Greek Theatre: New Views of an Old Subject. Iowa: University of Iowa Press, 1999.

Bonfante, Larissa and Rolf Winkes. Bibliography of the Works of M. Bieber for her 90 $0^{\text {th }}$ Birthday. New York: [privately printed for Columbia University], 1969.

Bonfante, Larissa. "Margarete Bieber (1879-1978)." Gnomon 51 (1979): 621-624.

Bonfante, Larissa. "Margarete Bieber (1879-1978): An Archeologist in Two Worlds." In Women as Interpreters of the Visual Arts, 1820-1979, edited by Claire Richter Sherman and Adele M. Holcomb, 239-274. Connecticut: Greenwood Press, 1981.

Bonfante, Larissa. "Bieber, Margarete (1879-1978)." In Encyclopedia of the History of Classical Archaeology, edited by Nancy Thomson de Grummond, 159-160. New York: Routledge, 1996.

Broniewicz, Lucjan. “Tworzenie się inteligencji żydowskiej w Prusach Zachodnich. Żydowscy absolwenci gimnazjów przed 1914 rokiem." In Emancypacja - asymilacja - antysemityzm. Żydzi na Pomorzu w XIX i XX wieku, edited by Zenon Hubert Nowak, 27-41. Toruń: Wydawnictwo Adam Marszałek, 1992.

Buchholz, Hans-Günter. “Margarete Bieber (1879-1978) / Klassische Archäologin.” In Gießener Gelehrte in der ersten Hälfte des 20. Jahrhunderts, vol. 1, edited by Hans Georg Gundel, Peter Moraw and Volker Press, 58-73. Marburg: Elwert, 1982.

Calder III, William M. "Filologia klasyczna w Ameryce." Meander. Miesięcznik poświęcony kulturze świata starożytnego 49/7-8 (1994): 379-398.

Esden-Tempski, Kazimierz and Marian Sydow, eds. Księga pamiątkowa dziesięciolecia Pomorza 1920-1930. Toruń: Pomorska Drukarnia Rolnicza, 1930.

Faron, Aleksandra. "Przebieg inflacji markowej w II Rzeczypospolitej." Studia Ekonomiczne 26 (2003): 33-49.

${ }^{78} \mathrm{~W}$ bibliografii nie zostały odnotowane przywołane w artykule prace autorstwa Margarete Bieber. 
Freidenreich, Harriet Pass. Female, Jewish, Educated: The Lives of Central European University Women. Bloomington: Indiana University Press, 2002.

Gerlich, Gustav. Statistische Beschreibung des Schwetzer Kreises. Schwetz: J. Bauffe, 1878.

Golon, Mirosław. "Gmina Wyznaniowa Żydowska w Świeciu nad Wisłą w latach 1920-1939.” In Gminy Wyznaniowe Żydowskie w województwie pomorskim w okresie międzywojennym (1920-1939), edited by Jan Sziling, 173-202. Toruń: Wydawnictwo Naukowe Uniwersytetu Mikołaja Kopernika, 1995.

Heuer, Renate, ed. Lexikon deutsch-jüdischer Autoren, vol. 2. München-New Providence-London-Paris: De Gruyter, 1993.

Jacobson, Emil. Topographisch-statistisches Handbuch für die Regierungsbezirk Marienwerder. Danzig: A. W. Kafemann, 1868.

Karpus, Zbigniew. “Żydzi w Świeciu i powiecie w okresie międzywojennym.” In Emancypacja - asymilacja - antysemityzm. Żydzi na Pomorzu w XIX i XX wieku, edited by Zenon Hubert Nowak, 109-121. Toruń: Wydawnictwo Adam Marszałek, 1992.

Kępczyńska, Krystyna. "Absolwenci Gimnazjum Toruńskiego w drugiej połowie XIX i na początku XX wieku.” Acta Universitatis Nicolai Copernici. Historia 11 (74) (1977): 113-131.

Kocur, Mirosław. Teatr antycznej Grecji. Wrocław: Wydawnictwo Uniwersytetu Wrocławskiego, 2001.

Kotlińska-Toma, Agnieszka. Tragedia hellenistyczna. Wrocław: Wydawnictwo Uniwersytetu Wrocławskiego, 2006.

Krzemiński, Tomasz. "Małe miasta Pomorza Nadwiślańskiego w dobie przemian cywilizacyjnych XIX wieku. Społeczność lokalna między zacofaniem a modernizacją." In Naród bez państwa na drogach do nowoczesności. Książka jubileuszowa w 70. rocznice urodzin Szczepana Wierzchosławskiego, edited by Magdalena Niedzielska, 103-124. Toruń: Wydawnictwo Naukowe Uniwersytetu Mikołaja Kopernika, 2017.

Kuras, Zbigniew. Przemyst na Pomorzu Gdańskim w latach 1920-1939. Bydgoszcz: IKN ODN, 1984.

Landau, Zbigniew and Jerzy Tomaszewski. Gospodarka Polski międzywojennej 1918-1939, vol. 1: W dobie inflacji 1918-1923. Warszawa: Książka i Wiedza, 1967.

Mazón, Patricia M. Gender and the Modern Research University: The Admission of Women to German Higher Education, 1865-1914. Stanford: Stanford University Press, 2003.

Niedzielska, Magdalena. “Życie polityczne i kulturalne Torunia (1815-1914).” In Historia Torunia, vol. 3/1: W czasach zaboru pruskiego (1793-1920), edited by Marian Biskup, 220-389. Toruń: TNT, 2003.

Niewęgłowska, Aneta. Średnie szkolnictwo żeńskie $w$ Prusach Zachodnich $w$ latach 1815-1914. Toruń: TNT, 2014.

Niewęgłowska, Aneta. “Średnie szkolnictwo żeńskie w Toruniu w latach 1820-1920.” Rocznik Toruński 31 (2004): 101-135.

Obermayer, Hans Peter. Deutsche Altertumswissenschaftler im amerikanischen Exil. Eine Rekonstruktion. Berlin-Boston: De Gruyter, 2014. 
Podlaszewska, Krystyna. Gimnazjum Toruńskie w latach 1817-1920. Toruń: Wydawnictwo Naukowe Uniwersytetu Mikołaja Kopernika, 2007.

Rasmus, Hugo. Lebensbilder Westpreussischer Frauen in Vergangenheit und Gegenwart. Münster/Westf: Nicolaus-Copernicus-Verlag, 1984.

Recke, Matthias. “....besonders schauerlich war die Anwesenheit von Frl. Bieber.' Die Archäologin Margarete Bieber (1879-1978) - Etablierung einer Frau als Wissenschaftlerin." In Science oder Fiction? Geschlechterrollen in archäologischen Lebensbildern, edited by Jana Esther Fries, Ulrike Rambuscheck and Gisela SchulteDornberg, 209-231. Münster: Waxmann, 2007.

Recke, Matthias. "Bieber, Margarete." In Geschichte der Altertumswissenschaften. Biographisches Lexikon, edited by Peter Kuhlmann and Helmuth Schneider, 103-105. Stuttgart, Weimar: Metzler, 2012.

Recke, Matthias. "Margarete Bieber (1879-1978) - Vom Kaiserreich bis in die Neue Welt. Ein Jahrhundert gelebte Archäologie gegen alle Widerstände." In Ausgräberinnen, Forscherinnen, Pionierinnen. Ausgewählte Porträts früher Archäologinnen in Kontext ihrer Zeit, edited by Jana Esther Fries and Doris Gutsmiedl-Schümann, 141-149. Münster: Waxmann, 2013.

Rudavsky, Shari. “Marie Curie 1867-1934.” In Notable Scientists from 1900 to the Present, vol. 1: $A-C$, edited by Brigham Narins, 497-500. Farmington Hills: Gale Group, 2001.

Schanz, Holly Lee. Review of Ancient Copies: Contributions to the History of Greek and Roman Art, by Margarete Bieber. The Art Bulletin 62/2 (1980): 307-309.

Seyfert, Ernst. Güter-Adreßbuch für die Provinz Westpreussen. Leipzig: Reichenbachsche Verlagsbuchhandlung, 1912.

Smentek, Lidia. "Nawojka gimnazjum Toruńskiego: Margarete Bieber." Zeszyty Literackie i Naukowe I LO im. Mikołaja Kopernika w Toruniu 4 (2018): 21-58.

Skuczyński, Piotr. Przechowo. Album z zarysem dziejów. Świecie: Studio Grafiki Komputerowej M\&M Graphic, 2014.

Srebrny, Stefan. Teatr grecki i polski. Warszawa: Państwowe Wydawnictwo Naukowe, 1984.

Stażewski, Marek. Exodus. Migracja ludności niemieckiej z Pomorza do Rzeszy po I wojnie światowej. Gdańsk: Wydawnictwo Uniwersytetu Gdańskiego, 1998.

Tetzlaff, Walter. "Bieber, Margarete." In Altpreussische Biographie, vol. 4/2, edited by Ernst Bahr and Gerd Brausch, 1181. Marburg/Lahn: Elwert, 1989.

Wajda, Kazimierz. "Świecie i powiat świecki w czasach zaboru pruskiego (1815-1919)." In Dzieje Świecia i jego regionu, vol. 1, edited by Kazimierz Jasiński, 283-351. Warszawa, Poznań, Toruń: PWN, 1979.

Wilkins, Ann Thomas. “Bieber, Margarete." In Notable American Women: A Biographical Dictionary Completing the Twentieth Century, edited by Susan Ware and Stacy Braukman, 56-57. Harvard: Belknap Press, 2004.

Żebrowski, Rafał. "Hochschule für die Wissenschaft des Judentums." In Polski Słownik Judaistyczny. Dzieje, kultura, religia, ludzie, vol. 1, edited by Zofia Borzymińska and Rafał Żebrowski, 605. Warszawa: Prószyński i S-ka, 2003. 